\title{
Evaluation and Management of Osteoporosis and Sarcopenia in Patients with Distal Radius Fractures
}

\author{
Gajendra Mani Shah, MD, Hyun Sik Gong, MD*, Young Ju Chae, MD*, \\ Yeun Soo Kim, MD*, Jihyeung Kim, $\mathrm{MD}^{\dagger}$, Goo Hyun Baek, $\mathrm{MD}^{\dagger}$ \\ Department of Orthopedics and Trauma Surgery, Patan Academy of Health Sciences, Lalitpur, Nepal, \\ * Department of Orthopedic Surgery, Seoul National University Bundang Hospital, Seongnam, \\ ${ }^{\dagger}$ Department of Orthopedic Surgery, Seoul National University Hospital, Seoul, Korea
}

Distal radius fractures (DRFs) are one of the most common fractures seen in elderly people. Patients with DRFs have a high incidence of osteoporosis and an increased risk of subsequent fractures, subtle early physical performance changes, and a high prevalence of sarcopenia. Since DRFs typically occur earlier than vertebral or hip fractures, they reflect early changes of the bone and muscle frailty and provide physicians with an opportunity to prevent progression of frailty and secondary fractures. In this review, we will discuss the concept of DRFs as a medical condition that is at the start of the fragility fracture cascade, recent advances in the diagnosis of bone fragility including emerging importance of cortical porosity, fracture healing with osteoporosis medications, and recent progress in research on sarcopenia in patients with DRFs.

Keywords: Radius fractures, Osteoporosis, Sarcopenia, Osteoporotic fractures, Porosity

The World Health Organization has defined osteoporosis as a metabolic bone disease characterized by low bone mass and microarchitectural deterioration of bone tissue leading to enhanced bone fragility and a consequent increase in fracture risk. ${ }^{1)}$ It has been estimated that more than 200 million people are suffering from osteoporosis. ${ }^{2)}$ In 2008 , about $40 \%$ of women in Korea were reported to have osteoporosis. ${ }^{3)}$ On the other hand, sarcopenia is defined as the loss of muscle mass and muscle strength and functional impairment of muscles with aging, which compromises physical performance. It is closely associated with fractures and has been investigated as a new independent risk factor for fragility fractures, leading to a condition known as osteosarcopenia. ${ }^{4,5}$ Osteoporosis and sarcopenia are predominantly common in older individuals,

Received July 29, 2019; Accepted October 21, 2019

Correspondence to: Hyun Sik Gong, MD

Department of Orthopedic Surgery, Seoul National University Bundang Hospital, Seoul National University College of Medicine, 82 Gumi-ro 173beongil, Bundang-gu, Seongnam 13620, Korea

Tel: +82-31-787-7198, Fax: +82-31-787-4056

E-mail: hsgong@snu.ac.kr resulting in increased morbidity, mortality, and healthcare costs. $^{6,7)}$

Distal radius fractures (DRFs) are the most common upper extremity fracture in middle-aged and elderly people with an overall higher incidence in women. ${ }^{8)}$ The incidence of DRFs is rising in recent decades. A study from the USA found a $17 \%$ increase in the incidence of this injury over a 40 -year period, and in Sweden the incidence almost doubled for the older population over a 30-year time span. ${ }^{9,10)}$ The proportion of DRFs treated by surgery tended to increase over time, from $32.6 \%$ in 2011 to $38.3 \%$ in 2015 in Korea. ${ }^{11)}$

Osteoporosis is an independent risk factor for lowenergy DRFs in the elderly population and hence should not be missed in managing DRFs. Studies have shown that patients with DRFs have a high incidence of osteoporosis and an increased risk of subsequent fractures, subtle early physical performance changes, and a high prevalence of sarcopenia. ${ }^{12,13)}$ Since DRFs typically occur 15 years earlier than hip fractures, they reflect early changes of the bone and muscle frailty and provide physicians with an opportunity to prevent progression of frailty and secondary fractures. ${ }^{13,14)}$ Since our last review on the evaluation of bone 
Shah et al. Osteoporosis and Sarcopenia in Distal Radius Fractures

Clinics in Orthopedic Surgery • Vol. 12, No. 1, $2020 \bullet$ www.ecios.org

frailty in DRF patients, ${ }^{15)}$ new information has emerged, including the importance of cortical porosity and muscle frailty in these patients. Therefore, in this review, we will discuss the concept of DRFs as a medical condition that starts the fragility fracture cascade, recent advances in the diagnosis of bone fragility including emerging importance of cortical porosity, fracture healing with osteoporosis medications, and recent progress in research on sarcopenia in DRF patients.

\section{DIAGNOSIS OF OSTEOPOROSIS AND ITS INCIDENCE IN PATIENTS WITH DRFS}

The diagnosis of osteoporosis is based on dual-energy Xray absorptiometry (DXA), which is the reference standard for determining bone mineral density (BMD). ${ }^{16)}$ Several previous studies have shown that BMD is lower in patients with a DRF than in those without a fracture. ${ }^{17-20)}$ However, a few studies have found no difference between patients and controls. ${ }^{21,22)}$ Table 1 shows the prevalence of osteoporosis in patients with DRFs. ${ }^{18-20,22-28)}$ A study by Lee et al. ${ }^{24)}$ in a Korean female population found that patients aged 50 to 59 years and 70 to 79 years who had DRFs had statistically significantly lower BMD at the hip than did the reference Korean female population.

While areal BMD (aBMD) measurement is a significant predictor of fracture risk, its value is limited because it is a two-dimensional technique and affected by the size and position of the subject and it cannot distinguish between cortical and trabecular compartments. ${ }^{25,29,30)}$ Moreover, BMD is not consistently lower in patients with a DRF than in normal controls and over $80 \%$ of fractures occur in women who would not be classified as osteoporotic according to current BMD criteria. ${ }^{21,22,24)}$ These suggest that factors other than BMD, such as bone microarchitecture, bone geometry, microdamage, mineralization, bone turnover, and propensity to fall, influence bone strength and fracture risk..$^{13,30)}$

\section{RECENT ADVANCES IN THE DIAGNOSIS OF BONE FRAGILITY IN PATIENTS WITH DRFS}

Trabecular bone score (TBS) was introduced as a tool for assessing trabecular microarchitecture and has been used in many clinical and research fields. TBS is a textural index that evaluates pixel gray-level variations in the lumbar spine DXA image (Fig. 1). ${ }^{31)}$ It provides an indirect index of trabecular microarchitecture and bone quality. TBS has shown significant association with fractures in several studies. ${ }^{32,33)}$ In patients with DRFs, however, Shin et al. ${ }^{15)}$ found that TBS was not different from that in those without a fracture, although hip BMD was significantly lower in patients with DRFs. Their result suggests that TBS measured at the lumbar spine does not reflect early microarchitectural changes of the distal radius and only hip BMD is associated with the risk of DRFs.

BMD measured by quantitative computed tomography (QCT) provides a true volumetric BMD measure and it is not size dependent as in DXA. DXA measures integral (cortical and trabecular) aBMD, whereas QCT allows separate measurement of BMD of the trabecular and cortical bone compartments, enabling greater understanding of the effects of disease and treatment on bone. ${ }^{34)}$

$\mathrm{CT}$ determines X-ray attenuation coefficient normalized to Hounsfield unit (HU) values (Fig. 2). HU values are measured by using the standard PACS (Picture Archiving and Communication System) software tool. A calibration phantom is required to be scanned with the patient to convert the $\mathrm{HU}$ into the bone mineral unit. This phantom contains various concentrations $\left(\mathrm{g} / \mathrm{cm}^{3}\right)$ of calcium hydroxyapatite or equivalent and is used to interpolate BMD based on the HU. ${ }^{35,36)}$ Previous biomechanical study has shown that an increase in the HU value is correlated linearly with an increase in material density. HU values showed a decreasing trend with increasing age and decreasing BMD. ${ }^{37,38)}$ Johnson et al. ${ }^{38)}$ found that BMD and T-scores significantly correlate with the capitate trabecular $\mathrm{HU}$ in patients with wrist fractures. A capitate threshold of $307 \mathrm{HU}$ maximizes sensitivity and specificity for detecting osteoporosis. High radiation exposure and low resolution imaging are the greatest disadvantages of this method. ${ }^{39}$ Currently, CT performed for other reasons such as fracture assessment is termed as opportunistic use. Such use of CT may increase screening rates or preclude DXA screening in some individuals. ${ }^{40)}$

High-resolution peripheral QCT (HR-pQCT) is a noninvasive approach, which enables in vivo three-dimensional analysis of bone microstructure at the appendicular skeleton. ${ }^{41)}$ HR-pQCT allows the analysis of geometric, microstructural, densitometric, and mechanical properties of the trabecular and cortical bone architecture in the distal radius and tibia. ${ }^{41,42)}$ In addition, the micro-finite element analysis permits the estimation of bone strength. ${ }^{43)}$

\section{CORTICAL POROSITY AND DRFS}

Cortical bone comprises approximately $70 \%$ mineralized matrix, and trabecular (spongy) bone comprises 10\%-30\% mineralized bone matrix fashioned as plates and rods occupying the medullary canal. ${ }^{44)}$ As $80 \%$ of the skeleton 
is cortical bone, the size and number of porosity in this region play a critical role in bone strength. ${ }^{45)}$ Even a small increase in porosity of cortex compromises stiffness to a greater extent than does the similar increase in an already highly porous trabecular bone. ${ }^{46}$

Bala et al. ${ }^{47)}$ analyzed HR-pQCT in 100 postmenopausal women aged above 50 years with a forearm fracture and 105 controls and found that women with a fracture

\section{Table 1. Incidence of Osteoporosis in Patients with Distal Radius Fractures (DRFs)}

\begin{tabular}{|c|c|c|c|c|c|c|c|}
\hline Study & $\begin{array}{l}\text { No. of } \\
\text { subjects }\end{array}$ & $\begin{array}{l}\text { Mean } \\
\text { age (yr) }\end{array}$ & \multicolumn{2}{|c|}{$\begin{array}{l}\text { Osteoporosis based } \\
\text { on lumbar BMD or } \\
\text { T-score }\end{array}$} & $\begin{array}{l}\text { Osteoporosis based on } \\
\text { hip BMD or T-score }\end{array}$ & $\begin{array}{c}\text { Overall } \\
\text { osteoporosis }\end{array}$ & Comment \\
\hline $\begin{array}{l}\text { Earnshaw } \\
(1998)^{18)}\end{array}$ & 106 & 65.7 & \multicolumn{2}{|l|}{$\begin{array}{l}<65 \text { yr: } 17 \% \\
\geq 66 \text { yr: } 24 \%\end{array}$} & $\begin{array}{l}<65 \text { yr: } 24 \% \\
\geq 66 \text { yr: } 55 \%\end{array}$ & $50 \%$ & \\
\hline $\begin{array}{l}\text { Hegeman et al. } \\
(2004)^{19)}\end{array}$ & 94 & 69 & \multicolumn{2}{|c|}{$\begin{array}{l}<65 \text { yr: T-score, } \\
-1.41 \text { (SD, 1.49) } \\
\geq 66 \text { yr: T-score, } \\
-2.16 \text { (SD, 1.53) }\end{array}$} & $\begin{array}{l}<65 \text { yr: T-score, } \\
-1.17 \text { (SD, 1.00) } \\
\geq 66 \text { yr: T-score, } \\
-1.75 \text { (SD, 0.92) }\end{array}$ & $\begin{array}{c}51 \% \\
\text { Low BMD: } 85 \%\end{array}$ & \\
\hline $\begin{array}{l}\text { Sosa et al. } \\
(2005)^{221}\end{array}$ & 469 & 62.6 & \multicolumn{3}{|c|}{\begin{tabular}{ccc}
\multicolumn{3}{c}{ Calcaneus Quantitative Ultrasound index } \\
DRF group & Control & $p$-value \\
Z-score: $-0.55 \pm 0.90$ & $-0.52 \pm 1.03$ & 0.707 \\
T-score: $-1.52 \pm 0.86$ & $-1.41 \pm 0.97$ & 0.254
\end{tabular}} & & $\begin{array}{l}p \text {-values were not } \\
\text { significant. }\end{array}$ \\
\hline $\begin{array}{l}\text { Lofman et al. } \\
(2007)^{20)}\end{array}$ & 171 & 67 & & & $\begin{array}{l}50-59 \text { yr: } 19 \% \\
60-69 \text { yr: } 15 \% \\
70-79 \text { yr: } 83 \%\end{array}$ & $\begin{array}{l}\text { Osteoporosis: } 37 \% \\
\text { Osteopenia: } 52 \%\end{array}$ & \\
\hline $\begin{array}{l}\text { Lashin and } \\
\text { Davie } \\
(2008)^{23)}\end{array}$ & 186 & 65.5 & & & $\begin{array}{l}50-64 \text { yr: } 31.1 \% \\
65-74 \text { yr: } 34.4 \% \\
>75 \text { yr: } 40 \%\end{array}$ & $33.9 \%$ & \\
\hline $\begin{array}{l}\text { Lee et al. } \\
(2010)^{24)}\end{array}$ & 54 & 64 & \multicolumn{2}{|l|}{$\begin{array}{l}50-59 \text { yr: } 38 \% \\
60-69 \text { yr: } 34 \% \\
70-79 \text { yr: } 67 \%\end{array}$} & \multicolumn{2}{|r|}{$57.4 \%$} & \\
\hline $\begin{array}{l}\text { Oyen et al. } \\
(2011)^{25)}\end{array}$ & $\begin{array}{l}664 \text { Women, } \\
85 \text { men }\end{array}$ & 66 & $\begin{array}{l}\text { Women } \\
\text { Osteoporosis: } 39 \% \\
\text { Osteopenia: } 34 \%\end{array}$ & $\begin{array}{l}\text { Men } \\
23 \% \\
42 \%\end{array}$ & $\begin{array}{rc}\text { Women } & \text { Men } \\
\text { 50-59 yr: 18\%/59\% } & 50-59 \text { yr: } 17 \% / 64 \% \\
60-69 \text { yr: } 25 \% / 46 \% & 50-64 \text { yr: } 14 \% /- \\
65-90 \text { yr: } 51 \% / 40 \% & 64-90 \text { yr: 20\%/- } \\
& \end{array}$ & $\begin{array}{l}\text { Women: } 34 \% \text { OR } \\
\text { (95\% CI) } \\
\text { Osteoporosis: } 7.1 \\
\text { (4.3-11.6) } \\
\text { Osteopenia: } 2.7 \\
\text { (1.9-3.9) } \\
\text { Men: } 17 \% \\
\text { Osteoporosis: } 8.5 \\
\text { (1.6-4.7) } \\
\text { Osteopenia: } 3.4 \\
\text { (1.1-10.5) }\end{array}$ & $\begin{array}{l}\text { Osteoporosis was } \\
\text { significantly } \\
\text { associated with } \\
\text { low-energy } \\
\text { distal radial } \\
\text { fracture. }\end{array}$ \\
\hline $\begin{array}{l}\text { Jang et al. } \\
(2012)^{26)}\end{array}$ & 104 Women & 65 & & & $\begin{array}{l}\text { Femoral neck BMD } \\
\text { DRF Group: } 0.65 \pm 0.16(0.20-1.07) \\
\text { Control: } 0.70 \pm 0.14(0.28-1.01)(p=0.03)\end{array}$ & & $\begin{array}{l}\text { Hip BMDs were } \\
\text { significantly } \\
\text { lower in the DRF } \\
\text { group than in the } \\
\text { control group. }\end{array}$ \\
\hline $\begin{array}{l}\text { Massey et al. } \\
(2015)^{277}\end{array}$ & 128 Women & $\begin{array}{l}\text { Group } 1 \\
\text { (35-50 yr) } \\
\text { Group } 2 \\
(>50 \mathrm{yr})\end{array}$ & $\begin{array}{r}\text { Group 1: Osteoporosis } \\
\text { Osteopenia, } \\
\text { Group 2: Osteoporosis } \\
\text { Osteopenia, }\end{array}$ & $\begin{array}{l}17 \% \\
23 \% \\
27 \%\end{array}$ & $\begin{aligned} & \text { Group 1: Osteoporosis, 6\% } \\
& \text { Osteopenia, 43\% } \\
& \text { Group 2: Osteoporosis, 27\% } \\
& \text { Osteopenia, 48\% }\end{aligned}$ & & \\
\hline $\begin{array}{l}\text { Jung et al. } \\
(2016)^{28}\end{array}$ & 206 & $\begin{array}{l}\text { Group } 1 \\
\text { (50-59 yr) } \\
\text { Group 2 } \\
\text { (60-69 yr) } \\
\text { Group 3 } \\
\text { (70-79 yr) }\end{array}$ & $\begin{array}{l}\text { Lumbar BMD } \\
\text { Group 1: } 0.928 \pm 0.14 \\
\text { Control: } 1.004 \pm 0.15 p \\
\text { Group 2: } 0.831 \pm 0.12 \\
\text { Control: } 0.892 \pm 0.14 p \\
\text { Group 3: } 0.816 \pm 0.17 \\
\text { Control: } 0.848 \pm 0.16 p\end{array}$ & $\begin{array}{l}=0.132) \\
=0.527) \\
=0.724)\end{array}$ & $\begin{array}{l}\text { Femoral neck BMD } \\
\text { Group 1: } 0.802 \pm 0.10 \\
\text { Control: } 0.889 \pm 0.12(p<0.001) \\
\text { Group 2: } 0.745 \pm 0.09 \\
\text { Control: } 0.774 \pm 0.09(p=0.473) \\
\text { Group 3: } 0.670 \pm 0.08 \\
\text { Control: } 0.707 \pm 0.12(p=0.325)\end{array}$ & $51.5 \%$ & $\begin{array}{l}\text { Only the BMD in } \\
\text { the femur area } \\
\text { was significantly } \\
\text { lower in group } 1 \\
\text { (50-59 yr) than } \\
\text { in age-matched } \\
\text { controls. }\end{array}$ \\
\hline
\end{tabular}

Values are presented as mean \pm SD or mean \pm SD (range).

BMD: bone mineral density, SD: standard deviation, OR: odds ratio, Cl: confidence interval. 
Shah et al. Osteoporosis and Sarcopenia in Distal Radius Fractures

Clinics in Orthopedic Surgery • Vol. 12, No. 1, $2020 \bullet$ www.ecios.org

had micro-architectural deterioration, increased cortical porosity, and decreased trabecular bone volume fraction. They found significant correlations between the risk of a major fracture and cortical porosity. In women with osteopenia, the source of over $50 \%$ of all fractures, fracture risk was increased if high porosity was present. They found that only cortical porosity measured at ultradistal radius predicted fracture risk, independently of aBMD alone. Thus, measuring cortical porosity is clinically useful in identifying patients at risk for fractures, who can be considered at low risk on the basis of their aBMD measurement alone. ${ }^{47)}$

Biver et al. ${ }^{48)}$ investigated the independent contribution of cortical and trabecular volumetric BMD (vBMD) and microstructure as risk factors of incident fractures in a cohort of 740 community-dwelling postmenopausal women. They found that two-thirds of the women with fractures were not classified as osteoporotic by conventional DXA. For major osteoporotic fractures, the highest hazard ratio was obtained for the inner cortical porosity of the radius, which might reflect both cortical and trabecular compartments. They concluded that peripheral (ultradistal radius and tibia) cortical and trabecular vBMD and microstructure would predict a fracture independently of each other and other currently used tools such as femoral neck BMD, fracture risk assessment tool, and TBS.

\section{RISKS OF SUBSEQUENT FRACTURES IN PATIENTS WITH DRFS}

Many studies have shown that patients with DRFs have a greater probability of a subsequent fracture in later life

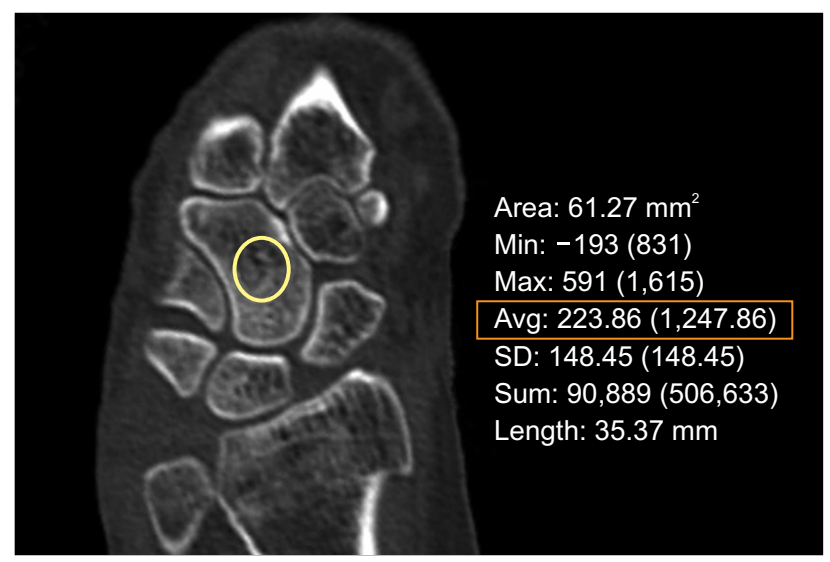

Fig. 2. Hounsfield unit measurement of the capitate in the coronal section of computed tomography with a circular region of interest with a diameter of $1 \mathrm{~cm}$. Min: minimum, Max: maximum, Avg: average, SD: standard deviation.
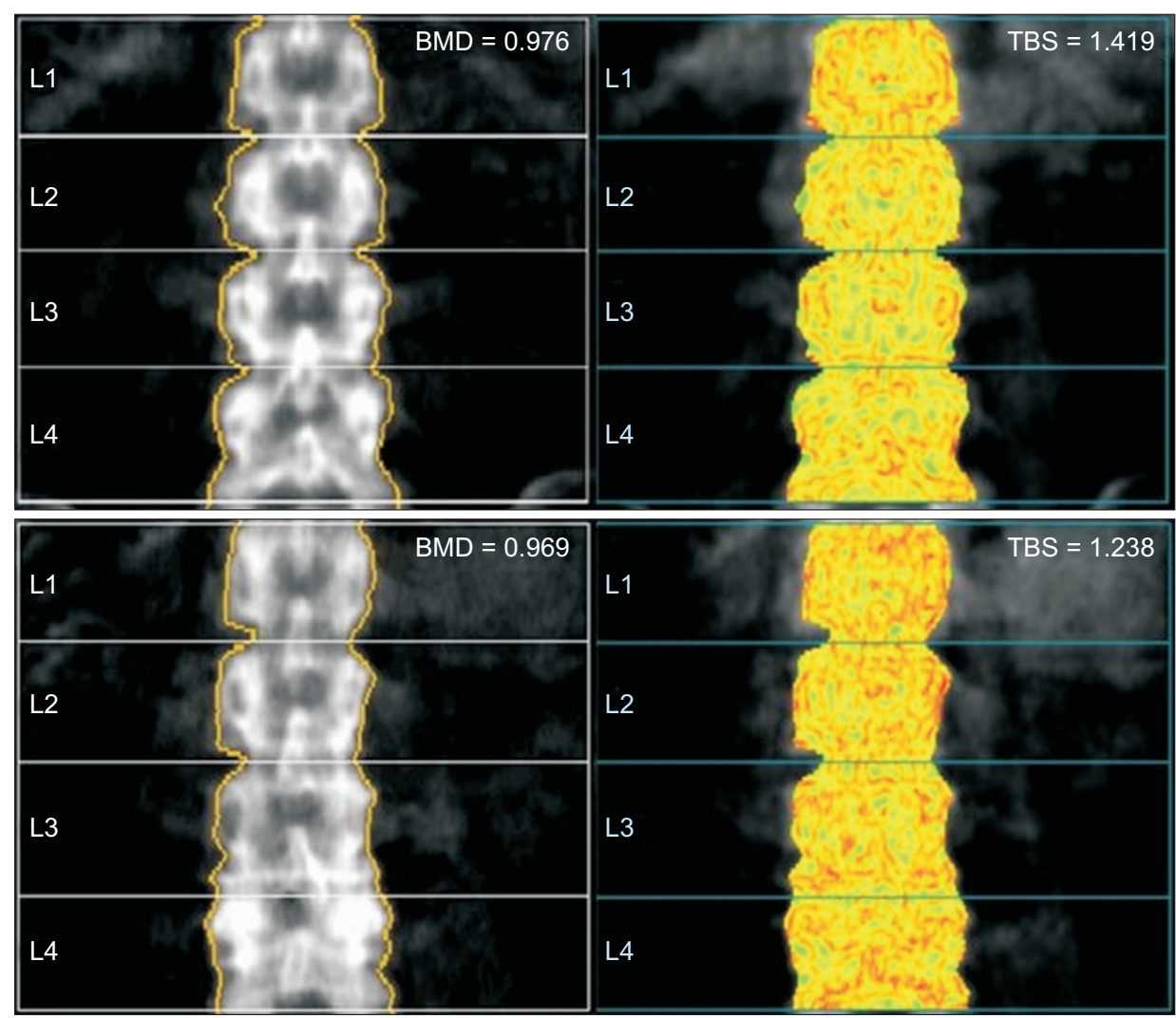



Fig. 1. The trabecular bone score (TBS) examination shows that the two patients with the same age (52 years) and similar bone mineral density (BMD) have different trabecular bone qualities. 
than those without previous DRFs. The association of prior wrist fractures and subsequent fractures is shown in Table 2 . $^{49-58)}$

A meta-analysis study by Haentjens et al ${ }^{53)}$ highlights that DRFs increased the relative risk (RR) of hip fractures more significantly in men than in women. The impact of a spine fracture, in contrast, did not differ between gen- ders). Owen et al. ${ }^{54)}$ showed that a DRF associated with minor trauma is indicative of an overall 50\% increase in the risk of a subsequent hip fracture. The RR of a subsequent hip fracture is greater for men with DRFs (RR, 6.4) than for women with DRFs (RR, 1.3). Other studies show similar results in which male have a greater chance of subsequent fractures than women irrespective of age. ${ }^{54,58)}$

\section{Table 2. Risks of Subsequent Fractures in Patients with Distal Radius Fractures (DRFs)}

\begin{tabular}{|c|c|c|c|c|c|}
\hline Study & Population & Country & Study type & $\begin{array}{c}\text { Subsequent fragility fracture } \\
\text { (RR/RH/HR/OR/SIR) }\end{array}$ & Comment \\
\hline $\begin{array}{l}\text { Owen et al. } \\
(1982)^{54)}\end{array}$ & & USA & $\begin{array}{l}\text { Retrospective } \\
\text { study }\end{array}$ & $\begin{array}{l}\text { Hip fracture } \\
\text { RR: } 6.4 \text { for men, } 1.3 \text { for women }\end{array}$ & $\begin{array}{l}\text { Overall } 50 \% \text { increase in the risk of a } \\
\text { subsequent hip fracture. }\end{array}$ \\
\hline $\begin{array}{l}\text { Mallmin et al. } \\
(1993)^{52)}\end{array}$ & $\begin{array}{l}1,126 \text { Women, } 212 \text { men } \\
>40 \mathrm{yr}\end{array}$ & Sweden & Cohort study & RH: 2.27 for men, 1.54 for women & $\begin{array}{l}\text { The increased risk in the women was } \\
\text { independent of age at inclusion, but } \\
\text { that in the men was more pronounced } \\
\text { in the younger age groups. }\end{array}$ \\
\hline $\begin{array}{l}\text { Lauritzen et al. } \\
(1993)^{55)}\end{array}$ & $\begin{array}{l}\text { 1,162 Women } \\
20-99 \text { yr }\end{array}$ & Denmark & & $\begin{array}{l}\text { Hip fracture } \\
\text { RR: } 60-79 \mathrm{yr}, 1.9(95 \% \mathrm{Cl}, 1.3-2.6) \\
\text { RR: } 20-99 \mathrm{yr}, 1.8(95 \% \mathrm{Cl}, 1.3-2.2)\end{array}$ & $\begin{array}{l}\text { The relative risk of hip fracture was } \\
\text { highest within the first years after } \\
\text { a fracture of the radius or the } \\
\text { humerus. }\end{array}$ \\
\hline $\begin{array}{l}\text { Tuppurainen } \\
\text { et al. }(1995)^{57)}\end{array}$ & $\begin{array}{l}3,140 \text { Women } \\
53.4 \pm 2.8 \mathrm{yr}\end{array}$ & Finland & $\begin{array}{l}\text { Prospective } \\
\text { study }\end{array}$ & $\begin{array}{l}\text { Wrist fracture } \\
\text { RR: } 2.25(95 \% \mathrm{Cl}, 1.10-4.62)\end{array}$ & $\begin{array}{l}\text { Former history of fractures, low } \\
\text { baseline BMD, and use of alcohol } \\
\text { are predisposing factors associated } \\
\text { with premenopausal fractures, while } \\
\text { hormone replacement therapy is } \\
\text { protective in this respect. }\end{array}$ \\
\hline $\begin{array}{l}\text { Honkanen et al. } \\
(1997)^{56)}\end{array}$ & 12,162 Women & Norway & $\begin{array}{l}\text { Retrospective } \\
\text { study }\end{array}$ & HR: $1.9(95 \% \mathrm{Cl}, 1.6-2.3)$ & $\begin{array}{l}\text { Early premenopausal low-energy } \\
\text { wrist fracture is an indicator of low } \\
\text { peak BMD, which predisposes to } \\
\text { subsequent fractures in general. }\end{array}$ \\
\hline $\begin{array}{l}\text { Cuddihy et al. } \\
(2002)^{58)}\end{array}$ & $\begin{array}{l}1,288 \text { ( } 243 \text { Men, } 1,045 \\
\text { women) } \\
\geq 35 \mathrm{yr}\end{array}$ & USA & $\begin{array}{l}\text { Retrospective } \\
\text { cohort study }\end{array}$ & $\begin{array}{l}\text { Hip fracture } \\
\text { RR: } 1.4 \text { for women }(95 \% \mathrm{Cl}, 1.1-1.8) \\
2.7 \text { for men }(95 \% \mathrm{Cl}, 0.98-5.8) \\
\text { Vertebral fracture } \\
\text { RR: } 5.2 \text { for women }(95 \% \mathrm{Cl}, 4.5-5.9) \\
\quad 10.7 \text { for men }(95 \% \mathrm{Cl}, 6.7-16.3)\end{array}$ & \\
\hline $\begin{array}{l}\text { Haentjens et al. } \\
(2003)^{53)}\end{array}$ & 499 Men, 3,683 women & $\begin{array}{l}\text { USA, } \\
\text { Europe }\end{array}$ & $\begin{array}{l}\text { Meta-analysis } \\
\text { study }\end{array}$ & $\begin{array}{l}\text { Hip fracture } \\
\text { RR: } 1.53 \text { (95\% Cl, 1.34-1.74) } \\
\text { In older men RR: 3.26 (95\% Cl, 2.08-5.11) }\end{array}$ & $\begin{array}{l}\text { Fractures of the distal part of the radius } \\
\text { increased the RR of hip fracture more } \\
\text { significantly in men than in women. }\end{array}$ \\
\hline $\begin{array}{l}\text { Schousboe et } \\
\text { al. }(2005)^{501}\end{array}$ & $\begin{array}{l}\text { 9,704 Women } \\
>50 \mathrm{yr}\end{array}$ & USA & Cohort study & $\begin{array}{l}\text { Vertebral fracture } \\
\text { OR: } 1.72(95 \% \mathrm{Cl}, 1.31-2.25) \\
\text { Hip fracture } \\
\text { HR: } 1.43(95 \% \mathrm{Cl}, 1.17-1.74)\end{array}$ & \\
\hline $\begin{array}{l}\text { Oyen et al. } \\
(2010)^{511}\end{array}$ & $\begin{array}{l}218 \mathrm{Men}, 1,576 \text { women } \\
\geq 50 \mathrm{yr}\end{array}$ & Norway & Cohort study & $\begin{array}{l}\text { RR with a T-score } \leq-2.5 \\
\text { Men: } 16.3 \% \text { risk of hip fracture } \\
25.1 \% \text { risk of other osteoporotic } \\
\text { fractures } \\
\text { Women: } 18.2 \% \text { hip fracture } \\
34.7 \% \text { risk of other } \\
\text { osteoporotic fractures }\end{array}$ & $\begin{array}{l}\text { There is an increase in fracture risk } \\
\text { with increasing age and number of } \\
\text { previous fractures. }\end{array}$ \\
\hline $\begin{array}{l}\text { Amin et al. } \\
(2013)^{49}\end{array}$ & $\begin{array}{l}1,776 \text { Adolescents, } \leq 18 \mathrm{yr} \\
1,086 \text { Boys, } 11 \pm 4 \mathrm{yr} \\
690 \text { Girls, } 10 \pm 4 \mathrm{yr}\end{array}$ & USA & Cohort study & $\begin{array}{l}\text { At least one fragility fractures at } \geq 35 \mathrm{yr} \text { : } \\
144(13 \%) \text { in boys and } 74(11 \%) \text { in girls } \\
\text { Boy: SIR, } 1.9(95 \% \mathrm{Cl}, 1.6-2.3) \\
\text { Girl: SIR, } 1.0(95 \% \mathrm{Cl}, 0.8-1.2)\end{array}$ & $\begin{array}{l}\text { DRF in boys, but not in girls, is } \\
\text { associated with an increased risk for } \\
\text { fragility fractures as older adults. }\end{array}$ \\
\hline
\end{tabular}

RR: relative risk, $\mathrm{BH}$ : relative hazard, HR: hazard ratio, OR: odds ratio, SIR: standardized incidence ratio, Cl: confidence interval, BMD: bone mineral density. 
Shah et al. Osteoporosis and Sarcopenia in Distal Radius Fractures

Clinics in Orthopedic Surgery • Vol. 12, No. 1, $2020 \bullet$ www.ecios.org

Thus, a previous low-energy DRF in middle-aged and elderly patients have shown to be a predictor of osteoporosis and greater risk of subsequent fractures.

Hip geometry is known as a risk factor of osteoporotic hip fractures. ${ }^{59)}$ Shin et al. ${ }^{60)}$ reported that DRF patients had lower hip BMD; lower cortical thickness, crosssectional area, and section modulus; and higher buckling ratio than a control group. They suggested that mechanical factors, specifically the geometry of the weak proximal femur, may increase the risk of subsequent hip fractures in patients with DRFs. On lumbar geometry, Melton et al. ${ }^{61)}$ showed that the lumber spine vBMD, bone geometry (vertebral apparent cortical thickness), bone microstructure, bone strength, and spine load to bone strength ratio can be correlated with a predictor of vertebral fractures. These parameters have not been correlated with DRFs and will be a subject of further studies.

\section{TREATMENT OF OSTEOPOROTIC DRFS}

Traditionally, stable DRFs have been treated with closed reduction and cast immobilization with satisfactory clinical outcomes. ${ }^{62)}$ However, osteoporosis can compromise the maintenance of reduction achieved by cast application or pinning. ${ }^{63)}$ Molded casts frequently fail to prevent loss of reduction and, in particular, shortening of the radius, and percutaneous pinning is reported as ineffective in osteoporotic bone ${ }^{64,65)}$ Therefore, open reduction and internal fixation with a volar fixed-angle locking plate has become a popular option for the treatment of unstable DRFs. ${ }^{66-68)}$ In a recent randomized trial comparing nonoperative treatment with volar locking plate fixation for DRFs in elderly patients ( $\geq 70$ years), the Patient Rated Wrist Evaluation score, the Disabilities of Arm, Shoulder and Hand (DASH) score, and grip strength were better for the volar locking plate group at 3 months and 12 months whereas the complication rates were similar, suggesting a benefit of volar plating in the elderly patient. ${ }^{69)}$

Interestingly, conflicting results have been seen in literatures regarding the influence of osteoporosis on radiological and clinical outcomes of DRFs treated with open reduction and internal fixation with a volar locking plate $^{68,70-75)}$ Several studies have mentioned that rigid fixation using volar locking plates in DRF patients with osteoporosis provided radiological and clinical outcomes similar to those in DRF patients without osteoporosis. ${ }^{5,70,75,76)}$ However, some studies have shown that patients with osteoporosis have worse clinical outcomes than nonosteoporotic patients despite similar radiological outcomes. ${ }^{73,74)}$ Fitzpatrick et al. ${ }^{73)}$ reported that osteoporosis by BMD was a strong independent predictor of high DASH scores, and a decrease in BMD was associated with reduced grip strength. ${ }^{74)}$ Osteoporotic bone can negatively affect the mechanical property of fracture callus and impairs fracture healing especially in the early and later periods. ${ }^{77)}$

Several investigators have shown improved anatomic and functional outcomes with the use of autologous bone grafts to reconstruct the radial metaphysis. ${ }^{78,79)}$ However, harvesting bone grafts results in increased operative time, blood loss, postoperative pain, cost, and surgical complications. ${ }^{79)}$ Bone graft substitutes have been introduced, but with respect to outcome improvement, need for fixation, or healing time, which of the numerous types of bone graft substitutes can best replace autografts in DRFs remains to be elucidated. ${ }^{79)}$

\section{OSTEOPOROSIS TREATMENT AND FRACTURE HEALING}

Pharmacologic options for the treatment of osteoporosis include bisphosphonates, calcitonin, estrogens, estrogen agonist/antagonist, parathyroid hormone, and the receptor activator of nuclear factor kappa-B ligand inhibitor (denosumab) and humanized monoclonal antibody to sclerostin (romosozumab). ${ }^{80,81)}$

Controversies exist regarding osteoporosis therapy and fracture healing. Rozental et al. ${ }^{14)}$ compared healing rates assessed by radiographic union of DRF in patients on bisphosphonate therapy at the time of the injury to those not on the therapy. They found that bisphosphonate use was associated with a slightly longer time of fracture healing (approximately 6 days) compared to no therapy. However, a randomized study by Gong et al. ${ }^{82)}$ showed that early initiation of bisphosphonate treatment for patients with an osteoporotic DRF treated with volar locking plate fixation does not affect fracture healing or radiographic or clinical outcomes. Similarly, denosumab showed neither delay of the fracture healing nor contributions to other complications, even when it is administered at or near the time of the fracture in nonvertebral fractures. ${ }^{83)}$ One possible explanation is that although bisphosphonate and denosumab are antiresorptive by action, they (denosumab at high doses) delay callus remodeling and thus increase callus volume and provide mechanical strength. ${ }^{83)}$ Anabolic agents like teriparatide were shown to shorten time to healing of DRFs. However, due to high cost and good healing by the conventional management, routine use of teriparatide is not recommended in DRFs. ${ }^{84)}$

A newer anabolic agent romosozumab has been introduced and clinical trial data show its significant 
antifracture benefits. ${ }^{85)}$ Romosozumab is a humanized monoclonal antibody to sclerostin, an inhibitor of Wnt signaling pathways. When romosozumab binds to sclerostin, sclerostin cannot bind to the LRP-5/6 receptors and cannot exert its inhibitory effect, permitting the engagement of Wnt ligands with their coreceptors, resulting in an increase in bone formation and BMD. ${ }^{86)}$

\section{CARE GAP IN PATIENTS WITH DRFS}

Many studies show that rates of evaluation to identify osteoporosis and treatment following fragility fractures are inadequate, especially for patients with nonvertebral fractures (Table 3)..$^{14,58,87-90)}$ Only $2.8 \%$ of women over the age of 50 years with a DRF underwent a BMD scan, and only $22.9 \%$ were managed with osteoporosis medication in the USA ${ }^{87)}$ In Korea, Gong et al. ${ }^{90)}$ used the national cohort in 2007 and found that $8.7 \%$ the patients with DRFs underwent diagnostic bone density scans, whereas $22.5 \%$ with a hip fracture and $28.8 \%$ with a spine fracture underwent a bone density scan. Regarding reasons for this gap between fragility fractures and osteoporosis care, Andrade et al. ${ }^{88)}$ suggested that the problem may be at the level of the healthcare delivery system. There may be a clinical disconnection between the physicians who treat fragility fractures and physicians who are responsible for detecting and treating osteoporosis.

Studies have been also conducted regarding patient adherence to medication. Poor adherence to osteoporosis medication is often observed in postmenopausal women, and limited health literacy appears to be associated with this poor adherence. ${ }^{91)}$ In a study by Roh at al., ${ }^{91)}$ inadequate health literacy among patients who had sustained a DRF was associated with poor adherence to weekly oral, but not quarterly intravenous, bisphosphonates. Another study by Roh et al. ${ }^{92)}$ stated that younger age and unmarried status are significant factors for avoiding a test for osteoporosis while younger age and lower level of annual income are associated with discontinuing osteoporosis treatment.

\section{FRACTURE LIAISON SERVICE}

A fracture liaison service (FLS) is a multidisciplinary system approach to reduce subsequent fracture risk in patients with a recent fragility fracture by identifying them at or close to the time when they are treated at the hospital for fracture and providing them with easy access to osteoporosis care. ${ }^{93)}$ In this model of care, a patient is automatically enrolled in the assessment of risk for a secondary fracture and treatment is initiated to improve bone quality and strength. Kaufman et al. ${ }^{94)}$ have shown that compared to other models such as referral letters to primary care physicians or endocrinologists, the FLS model results in a higher rate of diagnosis and treatment with less attrition in the post fracture phase. The international Osteoporosis

\section{Table 3. Care Gap in Patients with Distal Radius Fractures (DRFs)}

\begin{tabular}{|c|c|c|c|c|c|}
\hline Study & $\begin{array}{l}\text { Sample } \\
\text { size }\end{array}$ & $\begin{array}{l}\text { Wrist fracture } \\
\text { evaluated for } \\
\text { osteoporosis }(\%)\end{array}$ & $\begin{array}{l}\text { Wrist fracture } \\
\text { treated for } \\
\text { osteoporosis (\%) }\end{array}$ & $\begin{array}{l}\text { Not evaluated/ } \\
\text { advised }(\%)\end{array}$ & Comment \\
\hline Freedman et al. $(2000)^{87)}$ & 1,162 & & 24 & & $\begin{array}{l}\text { There was a significant decrease in the rate } \\
\text { of treatment of osteoporosis with increasing } \\
\text { patient age at the time of the fracture. }\end{array}$ \\
\hline Cuddihy et al. $(2002)^{58)}$ & 343 & & & 70.8 & \\
\hline Andrade et al. $(2003)^{88)}$ & 1,620 & & 23 & & $\begin{array}{l}44 \% \text { of vertebral fractures and } 21 \% \text { of hip } \\
\text { fractures treated for osteoporosis. } \\
\text { Increasing age was associated with a } \\
\text { reduced likelihood of receiving osteoporosis } \\
\text { treatment. }\end{array}$ \\
\hline Rozental et al. $(2008)^{14)}$ & 240 & 21.3 & 27.5 & 78.7 & $\begin{array}{l}\text { Ordering a BMD can dramatically improve } \\
\text { osteoporosis evaluation and treatment rates } \\
\text { following DRF. }\end{array}$ \\
\hline Gong et al. $(2009)^{90)}$ & 61,234 & & 7.5 & & $\begin{array}{l}30.1 \% \text { of vertebral fractures and } 22.4 \% \text { of hip } \\
\text { fractures treated for osteoporosis. }\end{array}$ \\
\hline Sarfani et al. $(2014)^{89)}$ & 82 & 15 & & & \\
\hline
\end{tabular}

BMD: bone mineral density. 
Foundation in 2013 recommended setting up FLS for prevention of secondary fractures. ${ }^{95)}$

Regarding the outcomes of FLS, a study on comparative refracture rates of FLS in Ontario, Canada, reported that relative to distal radius, presenting with multiple fractures at screening was associated with a higher risk of refracture while presenting with an ankle fracture was associated with a lower risk of refracture. ${ }^{96)}$

\section{EVALUATION OF SARCOPENIA IN PATIENTS WITH DRFS}

Sarcopenia, a term first introduced in 1984 by Rosenberg, refers to age-related loss of muscle mass, and is thus a type of geriatric syndrome. ${ }^{97)}$ Sarcopenia is a known risk factor for both falls and fractures. Reduced muscle strength makes it more difficult to regain lost balance and decreases the mechanical loading of the skeleton, leading to reduced adaptive bone remodeling. ${ }^{98,99)}$

Studies suggest that patients with DRFs show subtle early changes in physical performance and muscle strength. ${ }^{13,99)}$ Cho et al. ${ }^{13)}$ compared physical performance measures and fall risk factors in patients with recent DRFs and in age-matched control patients. Although there were no significant differences in the Short Physical Performance Battery Summary score, the Chair Stand score and grip strength were significantly lower in patients than in the control group. Furthermore, Fujita et al. ${ }^{100)}$ showed that patients with DRFs have lower grip strength, prolonged Timed Up and Go test time and lower 2-Step test score than do controls.

Roh et al. ${ }^{12)}$ reported a higher prevalence of sarcopenia in patients with DRFs compared to age- and sexmatched controls. In this study, $30 \%$ of DRF patients were sarcopenic, whereas $17 \%$ of controls were within the sarcopenic criteria. The patient group had significantly lower lean body mass and weaker grip strength than the control group. However, there was no significant difference in gait speed between the two groups. Regarding the outcomes of treatment of DRFs, sarcopenic patients had similar radiologic outcomes but worse functional outcomes than control patients. ${ }^{101)}$

\section{VITAMIN D AND DRFs}

Vitamin D influences skeletal mineralization principally through the regulation of intestinal calcium absorption. Vitamin D deficiency leads to stimulation of parathyroid hormone secretion, resulting in increased bone resorption and hence bone mass loss. ${ }^{102)}$ It has been associated with hip and low-energy DRFs and also has a direct effect on muscle strength modulated by specific vitamin $\mathrm{D}$ receptors (VDRs) present in human muscle tissue. ${ }^{103,104)}$ In a study in Korean women, the mean vitamin D level was significantly lower in the DRF group than in the control group. ${ }^{26}$ Kim et al. ${ }^{105)}$ assessed the VDR expression in the skeletal muscles of the forearm by immunohistochemistry in patients with DRFs and found that patients with lower muscle mass showed a significantly lower cross-sectional area of a single muscle fiber but a higher level of VDR expression. They suggested that the VDR expression is increased and the use of vitamin D is maximized in these patients to compensate for reduced muscle mass. Several studies have shown that individuals with a low vitamin $\mathrm{D}$ status improve in both muscle strength and performance through vitamin D supplementation. ${ }^{106,107)}$

\section{CONCLUSIONS}

DRFs occur on average 15 years earlier than hip fractures and are a condition that is at the start of the fragility fracture cascade. Therefore, occurrence of a DRF can be considered for physicians as an important opportunity to diagnose and treat osteoporosis and sarcopenia to prevent a secondary fracture. However, there is still a care gap between fragility fractures and osteoporosis care, especially for DRFs. Systematic approaches to address this care gap, such as FLS, are now implemented and further studies are necessary to confirm the effectiveness of such approaches.

Because DRFs can reflect early changes of bone and muscle weakness, studies on characteristics of patients with DRFs can suggest some insights on how to prevent these aging processes. Previously, measurement of BMD by DXA was considered the standard method but not all patients with DRFs have osteoporosis defined by the current BMD criteria. Recent studies using other assessment technologies such as HR-pQCT highlight the importance of cortical porosity in predicting fractures. In addition, studies on physical performance and muscles in DRF patients suggest identifiable risk factors for falls or fractures, such as decreased grip strength. Further studies are necessary to better identify patients with an increased risk of fractures or falls and intervention strategies to strength the bone and muscle.

\section{CONFLICT OF INTEREST}

No potential conflict of interest relevant to this article was reported. 
Shah et al. Osteoporosis and Sarcopenia in Distal Radius Fractures

Clinics in Orthopedic Surgery • Vol. 12, No. 1, $2020 \bullet$ www.ecios.org

\section{REFERENCES}

1. Kanis JA. Assessment of fracture risk and its application to screening for postmenopausal osteoporosis: synopsis of a WHO report. WHO Study Group. Osteoporos Int. 1994;4(6):368-81.

2. Sozen T, Ozisik L, Basaran NC. An overview and management of osteoporosis. Eur J Rheumatol. 2017;4(1):46-56.

3. Kim KH, Lee K, Ko YJ, et al. Prevalence, awareness, and treatment of osteoporosis among Korean women: the Fourth Korea National Health and Nutrition Examination Survey. Bone. 2012;50(5):1039-47.

4. Chalhoub D, Cawthon PM, Ensrud KE, et al. Risk of nonspine fractures in older adults with sarcopenia, low bone mass, or both. J Am Geriatr Soc. 2015;63(9):1733-40.

5. Lee JK, Yoon BH, Oh CH, Kim JG, Han SH. Is sarcopenia a potential risk factor for distal radius fracture? Analysis using propensity score matching. J Bone Metab. 2018;25(2):99-106.

6. Patel HP, Syddall HE, Jameson K, et al. Prevalence of sarcopenia in community-dwelling older people in the UK using the European Working Group on Sarcopenia in Older People (EWGSOP) definition: findings from the Hertfordshire Cohort Study (HCS). Age Ageing. 2013;42(3):378-84.

7. Braithwaite RS, Col NF, Wong JB. Estimating hip fracture morbidity, mortality and costs. J Am Geriatr Soc. 2003;51(3):364-70.

8. Nellans KW, Kowalski E, Chung KC. The epidemiology of distal radius fractures. Hand Clin. 2012;28(2):113-25.

9. Bengner U, Johnell O. Increasing incidence of forearm fractures: a comparison of epidemiologic patterns 25 years apart. Acta Orthop Scand. 1985;56(2):158-60.

10. Melton LJ 3rd, Amadio PC, Crowson CS, O'Fallon WM. Long-term trends in the incidence of distal forearm fractures. Osteoporos Int. 1998;8(4):341-8.

11. Jo YH, Lee BG, Kim JH, et al. National surgical trends for distal radius fractures in Korea. J Korean Med Sci. 2017;32(7):1181-6.

12. Roh YH, Koh YD, Noh JH, Gong HS, Baek GH. Evaluation of sarcopenia in patients with distal radius fractures. Arch Osteoporos. 2017;12(1):5.

13. Cho YJ, Gong HS, Song CH, Lee YH, Baek GH. Evaluation of physical performance level as a fall risk factor in women with a distal radial fracture. J Bone Joint Surg Am. 2014;96(5):361-5.

14. Rozental TD, Makhni EC, Day CS, Bouxsein ML. Improving evaluation and treatment for osteoporosis following distal radial fractures: a prospective randomized interven- tion. J Bone Joint Surg Am. 2008;90(5):953-61.

15. Shin YH, Gong HS, Gang DH, Shin HS, Kim J, Baek GH. Evaluation of trabecular bone score in patients with a distal radius fracture. Osteoporos Int. 2016;27(12):3559-65.

16. Kanis JA, McCloskey EV, Johansson H, Oden A, Melton LJ 3rd, Khaltaev N. A reference standard for the description of osteoporosis. Bone. 2008;42(3):467-75.

17. Itoh S, Ohta T, Samejima H, Shinomiya K. Bone mineral density in the distal radius in a healthy Japanese population and in relation to fractures of the distal radius. J Hand Surg Br. 1999;24(3):334-7.

18. Earnshaw SA, Cawte SA, Worley A, Hosking DJ. Colles' fracture of the wrist as an indicator of underlying osteoporosis in postmenopausal women: a prospective study of bone mineral density and bone turnover rate. Osteoporos Int. 1998;8(1):53-60.

19. Hegeman JH, Oskam J, van der Palen J, Ten Duis HJ, Vierhout PA. The distal radial fracture in elderly women and the bone mineral density of the lumbar spine and hip. J Hand Surg Br. 2004;29(5):473-6.

20. Lofman O, Hallberg I, Berglund K, et al. Women with lowenergy fracture should be investigated for osteoporosis. Acta Orthop. 2007;78(6):813-21.

21. Nordvall H, Glanberg-Persson G, Lysholm J. Are distal radius fractures due to fragility or to falls? A consecutive case-control study of bone mineral density, tendency to fall, risk factors for osteoporosis, and health-related quality of life. Acta Orthop. 2007;78(2):271-7.

22. Sosa M, Saavedra P, Gomez-Alonso C, et al. Postmenopausal women with Colles' fracture have bone mineral density values similar to those of controls when measured with calcaneus quantitative ultrasound. Eur J Intern Med. 2005;16(8):561-6.

23. Lashin H, Davie MW. DXA scanning in women over 50 years with distal forearm fracture shows osteoporosis is infrequent until age 65 years. Int J Clin Pract. 2008;62(3):38893.

24. Lee JO, Chung MS, Baek GH, Oh JH, Lee YH, Gong HS. Age- and site-related bone mineral densities in Korean women with a distal radius fracture compared with the reference Korean female population. J Hand Surg Am. 2010;35(9):1435-41.

25. Oyen J, Brudvik C, Gjesdal CG, Tell GS, Lie SA, Hove LM. Osteoporosis as a risk factor for distal radial fractures: a case-control study. J Bone Joint Surg Am. 2011;93(4):34856. 
Shah et al. Osteoporosis and Sarcopenia in Distal Radius Fractures

Clinics in Orthopedic Surgery • Vol. 12, No. 1, $2020 \bullet$ www.ecios.org

26. Jang WY, Chung MS, Baek GH, Song CH, Cho HE, Gong HS. Vitamin D levels in post-menopausal Korean women with a distal radius fracture. Injury. 2012;43(2):237-41.

27. Massey PA, James JR, Bonvillain J, Nelson BG, Massey SR, Hollister A. Prevalence of low bone mineral density in younger versus older women with distal radius fractures. Am J Orthop (Belle Mead NJ). 2015;44(12):E493-6.

28. Jung HJ, Park HY, Kim JS, Yoon JO, Jeon IH. Bone mineral density and prevalence of osteoporosis in postmenopausal Korean women with low-energy distal radius fractures. J Korean Med Sci. 2016;31(6):972-5.

29. Stone KL, Seeley DG, Lui LY, et al. BMD at multiple sites and risk of fracture of multiple types: long-term results from the Study of Osteoporotic Fractures. J Bone Miner Res. 2003;18(11):1947-54.

30. Rubin CD. Emerging concepts in osteoporosis and bone strength. Curr Med Res Opin. 2005;21(7):1049-56.

31. Silva BC, Leslie WD, Resch H, et al. Trabecular bone score: a noninvasive analytical method based upon the DXA image. J Bone Miner Res. 2014;29(3):518-30.

32. Briot K, Paternotte S, Kolta S, et al. Added value of trabecular bone score to bone mineral density for prediction of osteoporotic fractures in postmenopausal women: the OPUS study. Bone. 2013;57(1):232-6.

33. Krueger D, Fidler E, Libber J, Aubry-Rozier B, Hans D, Binkley N. Spine trabecular bone score subsequent to bone mineral density improves fracture discrimination in women. J Clin Densitom. 2014;17(1):60-5.

34. Mackey DC, Eby JG, Harris F, et al. Prediction of clinical non-spine fractures in older black and white men and women with volumetric BMD of the spine and areal BMD of the hip: the Health, Aging, and Body Composition Study. J Bone Miner Res. 2007;22(12):1862-8.

35. Manhard MK, Nyman JS, Does MD. Advances in imaging approaches to fracture risk evaluation. Transl Res. 2017;181:1-14.

36. Schultz K, Wolf JM. Emerging technologies in osteoporosis diagnosis. J Hand Surg Am. 2019;44(3):240-3.

37. Schreiber JJ, Anderson PA, Rosas HG, Buchholz AL, Au AG. Hounsfield units for assessing bone mineral density and strength: a tool for osteoporosis management. J Bone Joint Surg Am. 2011;93(11):1057-63.

38. Johnson CC, Gausden EB, Weiland AJ, Lane JM, Schreiber JJ. Using Hounsfield units to assess osteoporotic status on wrist computed tomography scans: comparison with dual energy x-ray absorptiometry. J Hand Surg Am. 2016;41(7):767-74.

39. Link TM. Osteoporosis imaging: state of the art and ad- vanced imaging. Radiology. 2012;263(1):3-17.

40. Gausden EB, Nwachukwu BU, Schreiber JJ, Lorich DG, Lane JM. Opportunistic use of CT imaging for osteoporosis screening and bone density assessment: a qualitative systematic review. J Bone Joint Surg Am. 2017;99(18):1580-90.

41. MacNeil JA, Boyd SK. Accuracy of high-resolution peripheral quantitative computed tomography for measurement of bone quality. Med Eng Phys. 2007;29(10):1096-105.

42. Burghardt AJ, Kazakia GJ, Majumdar S. A local adaptive threshold strategy for high resolution peripheral quantitative computed tomography of trabecular bone. Ann Biomed Eng. 2007;35(10):1678-86.

43. Macneil JA, Boyd SK. Bone strength at the distal radius can be estimated from high-resolution peripheral quantitative computed tomography and the finite element method. Bone. 2008;42(6):1203-13.

44. Aaron JE, Francis RM, Peacock M, Makins NB. Contrasting microanatomy of idiopathic and corticosteroid-induced osteoporosis. Clin Orthop Relat Res. 1989;(243):294-305.

45. Bala Y, Zebaze R, Seeman E. Role of cortical bone in bone fragility. Curr Opin Rheumatol. 2015;27(4):406-13.

46. Burr D. Microdamage and bone strength. Osteoporos Int. 2003;14 Suppl 5:S67-72.

47. Bala Y, Zebaze R, Ghasem-Zadeh A, et al. Cortical porosity identifies women with osteopenia at increased risk for forearm fractures. J Bone Miner Res. 2014;29(6):1356-62.

48. Biver E, Durosier-Izart C, Chevalley T, van Rietbergen B, Rizzoli R, Ferrari S. Evaluation of radius microstructure and areal bone mineral density improves fracture prediction in postmenopausal women. J Bone Miner Res. 2018;33(2):328-37.

49. Amin S, Melton LJ 3rd, Achenbach SJ, et al. A distal forearm fracture in childhood is associated with an increased risk for future fragility fractures in adult men, but not women. J Bone Miner Res. 2013;28(8):1751-9.

50. Schousboe JT, Fink HA, Taylor BC, et al. Association between self-reported prior wrist fractures and risk of subsequent hip and radiographic vertebral fractures in older women: a prospective study. J Bone Miner Res. 2005;20(1):100-6.

51. Oyen J, Gjesdal CG, Brudvik C, et al. Low-energy distal radius fractures in middle-aged and elderly men and women: the burden of osteoporosis and fracture risk: a study of 1794 consecutive patients. Osteoporos Int. 2010;21(7):125767.

52. Mallmin H, Ljunghall S, Persson I, Naessen T, Krusemo UB, Bergstrom R. Fracture of the distal forearm as a forecaster of subsequent hip fracture: a population-based 
Shah et al. Osteoporosis and Sarcopenia in Distal Radius Fractures

Clinics in Orthopedic Surgery • Vol. 12, No. 1, $2020 \bullet$ www.ecios.org

cohort study with 24 years of follow-up. Calcif Tissue Int. 1993;52(4):269-72.

53. Haentjens P, Autier P, Collins J, Velkeniers B, Vanderschueren D, Boonen S. Colles fracture, spine fracture, and subsequent risk of hip fracture in men and women: a metaanalysis. J Bone Joint Surg Am. 2003;85(10):1936-43.

54. Owen RA, Melton LJ 3rd, Ilstrup DM, Johnson KA, Riggs BL. Colles' fracture and subsequent hip fracture risk. Clin Orthop Relat Res. 1982;(171):37-43.

55. Lauritzen JB, Schwarz P, McNair P, Lund B, Transbol I. Radial and humeral fractures as predictors of subsequent hip, radial or humeral fractures in women, and their seasonal variation. Osteoporos Int. 1993;3(3):133-7.

56. Honkanen R, Tuppurainen M, Kroger H, Alhava E, Puntila E. Associations of early premenopausal fractures with subsequent fractures vary by sites and mechanisms of fractures. Calcif Tissue Int. 1997;60(4):327-31.

57. Tuppurainen M, Kroger H, Honkanen R, et al. Risks of perimenopausal fractures: a prospective population-based study. Acta Obstet Gynecol Scand. 1995;74(8):624-8.

58. Cuddihy MT, Gabriel SE, Crowson CS, et al. Osteoporosis intervention following distal forearm fractures: a missed opportunity? Arch Intern Med. 2002;162(4):421-6.

59. Gregory JS, Aspden RM. Femoral geometry as a risk factor for osteoporotic hip fracture in men and women. Med Eng Phys. 2008;30(10):1275-86.

60. Shin YH, Gong HS, Kim KM, Lee JH, Kwon O, Baek GH. Evaluation of hip geometry parameters in patients with a distal radius fracture. J Clin Densitom. 2019.

61. Melton LJ 3rd, Riggs BL, Keaveny TM, et al. Structural determinants of vertebral fracture risk. J Bone Miner Res. 2007;22(12):1885-92.

62. McQueen MM, Hajducka C, Court-Brown CM. Redisplaced unstable fractures of the distal radius: a prospective randomised comparison of four methods of treatment. J Bone Joint Surg Br. 1996;78(3):404-9.

63. Itoh S, Tomioka H, Tanaka J, Shinomiya K. Relationship between bone mineral density of the distal radius and ulna and fracture characteristics. J Hand Surg Am. 2004;29(1):123-30.

64. Greatting MD, Bishop AT. Intrafocal (Kapandji) pinning of unstable fractures of the distal radius. Orthop Clin North Am. 1993;24(2):301-7.

65. Arora R, Gabl M, Erhart S, Schmidle G, Dallapozza C, Lutz $M$. Aspects of current management of distal radius fractures in the elderly individuals. Geriatr Orthop Surg Rehabil. 2011;2(5-6):187-94.
66. Chung KC, Petruska EA. Treatment of unstable distal radial fractures with the volar locking plating system: surgical technique. J Bone Joint Surg Am. 2007;89 Suppl 2 Pt.2:25666.

67. Nana AD, Joshi A, Lichtman DM. Plating of the distal radius. J Am Acad Orthop Surg. 2005;13(3):159-71.

68. Lee JI, Park KC, Joo IH, Jeong HW, Park JW. The effect of osteoporosis on the outcomes after volar locking plate fixation in female patients older than 50 years with unstable distal radius fractures. J Hand Surg Am. 2018;43(8):731-7.

69. Saving J, Severin Wahlgren S, Olsson K, et al. Nonoperative treatment compared with volar locking plate fixation for dorsally displaced distal radial fractures in the elderly: a randomized controlled trial. J Bone Joint Surg Am. 2019;101(11):961-9.

70. Buyukkurt CD, Bulbul M, Ayanoglu S, Esenyel CZ, Ozturk $\mathrm{K}$, Gurbuz H. The effects of osteoporosis on functional outcome in patients with distal radius fracture treated with plate osteosynthesis. Acta Orthop Traumatol Turc. 2012;46(2):89-95.

71. Figl M, Weninger P, Jurkowitsch J, Hofbauer M, Schauer J, Leixnering M. Unstable distal radius fractures in the elderly patient: volar fixed-angle plate osteosynthesis prevents secondary loss of reduction. J Trauma. 2010;68(4):992-8.

72. Rhee SH, Kim J, Lee YH, Gong HS, Lee HJ, Baek GH. Factors affecting late displacement following volar locking plate fixation for distal radial fractures in elderly female patients. Bone Joint J. 2013;95(3):396-400.

73. Fitzpatrick SK, Casemyr NE, Zurakowski D, Day CS, Rozental TD. The effect of osteoporosis on outcomes of operatively treated distal radius fractures. J Hand Surg Am. 2012;37(10):2027-34.

74. Roh YH, Lee BK, Noh JH, Oh JH, Gong HS, Baek GH. Factors delaying recovery after volar plate fixation of distal radius fractures. J Hand Surg Am. 2014;39(8):1465-70.

75. Choi WS, Lee HJ, Kim DY, et al. Does osteoporosis have a negative effect on the functional outcome of an osteoporotic distal radial fracture treated with a volar locking plate? Bone Joint J. 2015;97(2):229-34.

76. Voigt C, Plesz A, Jensen G, Katthagen C, Lill H. Volar locking plating for distal radial fractures: is osteoporosis associated with poorer functional results and higher complications rates? Chirurg. 2012;83(5):463-71.

77. Xu SW, Yu R, Zhao GF, Wang JW. Early period of fracture healing in ovariectomized rats. Chin J Traumatol. 2003;6(3):160-6.

78. Axelrod TS, McMurtry RY. Open reduction and internal fixation of comminuted, intraarticular fractures of the dis- 
Shah et al. Osteoporosis and Sarcopenia in Distal Radius Fractures

Clinics in Orthopedic Surgery • Vol. 12, No. 1, $2020 \bullet$ www.ecios.org

tal radius. J Hand Surg Am. 1990;15(1):1-11.

79. Ladd AL, Pliam NB. The role of bone graft and alternatives in unstable distal radius fracture treatment. Orthop Clin North Am. 2001;32(2):337-51, ix.

80. Cosman F, de Beur SJ, LeBoff MS, et al. Clinician's guide to prevention and treatment of osteoporosis. Osteoporos Int. 2014;25(10):2359-81.

81. Russow G, Jahn D, Appelt J, Mardian S, Tsitsilonis S, Keller J. Anabolic therapies in osteoporosis and bone regeneration. Int J Mol Sci. 2018;20(1):E83.

82. Gong HS, Song CH, Lee YH, Rhee SH, Lee HJ, Baek GH. Early initiation of bisphosphonate does not affect healing and outcomes of volar plate fixation of osteoporotic distal radial fractures. J Bone Joint Surg Am. 2012;94(19):172936.

83. Adami S, Libanati C, Boonen S, et al. Denosumab treatment in postmenopausal women with osteoporosis does not interfere with fracture-healing: results from the FREEDOM trial. J Bone Joint Surg Am. 2012;94(23):2113-9.

84. Aspenberg P, Genant HK, Johansson T, et al. Teriparatide for acceleration of fracture repair in humans: a prospective, randomized, double-blind study of 102 postmenopausal women with distal radial fractures. J Bone Miner Res. 2010;25(2):404-14.

85. Saag KG, Petersen J, Brandi ML, et al. Romosozumab or alendronate for fracture prevention in women with osteoporosis. N Engl J Med. 2017;377(15):1417-27.

86. Bandeira L, Lewiecki EM, Bilezikian JP. Romosozumab for the treatment of osteoporosis. Expert Opin Biol Ther. 2017;17(2):255-63.

87. Freedman KB, Kaplan FS, Bilker WB, Strom BL, Lowe RA. Treatment of osteoporosis: are physicians missing an opportunity? J Bone Joint Surg Am. 2000;82(8):1063-70.

88. Andrade SE, Majumdar SR, Chan KA, et al. Low frequency of treatment of osteoporosis among postmenopausal women following a fracture. Arch Intern Med. 2003;163(17):2052-7.

89. Sarfani S, Scrabeck T, Kearns AE, Berger RA, Kakar S. Clinical efficacy of a fragility care program in distal radius fracture patients. J Hand Surg Am. 2014;39(4):664-9.

90. Gong HS, Oh WS, Chung MS, Oh JH, Lee YH, Baek GH. Patients with wrist fractures are less likely to be evaluated and managed for osteoporosis. J Bone Joint Surg Am. 2009;91(10):2376-80.

91. Roh YH, Noh JH, Gong HS, Baek GH. Comparative adherence to weekly oral and quarterly intravenous bisphosphonates among patients with limited heath literacy who sustained distal radius fractures. J Bone Miner Metab.
2018;36(5):589-95.

92. Roh YH, Lee ES, Ahn J, et al. Factors affecting willingness to get assessed and treated for osteoporosis. Osteoporos Int. 2019;30(7):1395-401.

93. Curtis JR, Silverman SL. Commentary: the five Ws of a Fracture Liaison Service. Why, who, what, where, and how? In osteoporosis, we reap what we sow. Curr Osteoporos Rep. 2013;11(4):365-8.

94. Kaufman JD, Bolander ME, Bunta AD, Edwards BJ, Fitzpatrick LA, Simonelli C. Barriers and solutions to osteoporosis care in patients with a hip fracture. J Bone Joint Surg Am. 2003;85(9):1837-43.

95. Akesson K, Marsh D, Mitchell PJ, et al. Capture the Fracture: a Best Practice Framework and global campaign to break the fragility fracture cycle. Osteoporos Int. 2013;24(8):2135-52.

96. Sujic R, Beaton DE, Mamdani M, et al. Five-year refracture rates of a province-wide fracture liaison service. Osteoporos Int. 2019;30(8):1671-7.

97. Santilli V, Bernetti A, Mangone M, Paoloni M. Clinical definition of sarcopenia. Clin Cases Miner Bone Metab. 2014;11(3):177-80.

98. He H, Liu Y, Tian Q, Papasian CJ, Hu T, Deng HW. Relationship of sarcopenia and body composition with osteoporosis. Osteoporos Int. 2016;27(2):473-82.

99. Benichou O, Lord SR. Rationale for strengthening muscle to prevent falls and fractures: a review of the evidence. Calcif Tissue Int. 2016;98(6):531-45.

100. Fujita K, Kaburagi H, Nimura A, et al. Lower grip strength and dynamic body balance in women with distal radial fractures. Osteoporos Int. 2019;30(5):949-56.

101. Roh YH, Noh JH, Gong HS, Baek GH. Effect of low appendicular lean mass, grip strength, and gait speed on the functional outcome after surgery for distal radius fractures. Arch Osteoporos. 2017;12(1):41.

102. Reid IR. Vitamin D effect on bone mineral density and fractures. Endocrinol Metab Clin North Am. 2017;46(4):935-45.

103. Oyen J, Apalset EM, Gjesdal CG, Brudvik C, Lie SA, Hove LM. Vitamin D inadequacy is associated with lowenergy distal radius fractures: a case-control study. Bone. 2011;48(5):1140-5.

104. Bakhtiyarova S, Lesnyak O, Kyznesova N, Blankenstein MA, Lips P. Vitamin D status among patients with hip fracture and elderly control subjects in Yekaterinburg, Russia. Osteoporos Int. 2006;17(3):441-6.

105. Kim K, Gong HS, Lim JY, Kim JH, Baek GH. The vitamin 
Shah et al. Osteoporosis and Sarcopenia in Distal Radius Fractures

Clinics in Orthopedic Surgery • Vol. 12, No. 1, $2020 \bullet$ www.ecios.org

D receptor expression in skeletal muscle of women with distal radius fracture. Arch Osteoporos. 2018;13(1):24.

106. Lee HJ, Gong HS, Song CH, Lee JE, Lee YH, Baek GH. Evaluation of vitamin $\mathrm{D}$ level and grip strength recovery in women with a distal radius fracture. J Hand Surg Am. 2013;38(3):519-25.
107. Visser M, Deeg DJ, Lips P; Longitudinal Aging Study Amsterdam. Low vitamin D and high parathyroid hormone levels as determinants of loss of muscle strength and muscle mass (sarcopenia): the Longitudinal Aging Study Amsterdam. J Clin Endocrinol Metab. 2003;88(12):5766-72. 